\title{
Different materials and techniques for accurate molding for adaptation in angled implants
}

\author{
Diferentes materiais e técnicas para moldagem precisa na adaptação em implantes inclinados
}

\author{
Lisliane Nara Rossi LEANDRO' \\ Rui Barbosa de BRITO JÚNIOR² \\ Marcelo Lucchesi TEIXEIRA ${ }^{2}$ \\ Luiz Martins TURANO² \\ Luciana Jardini da CUNHA ${ }^{3}$
}

\section{ABSTRACT}

\section{Objective}

To evaluate the marginal misfit between intermediate and micro-unitmetal cylinder, by varying the angle of the implants, using two different types of material and different molding techniques.

\section{Methods}

A model was made with three implants (one perpendicular to the horizontal plane and two inclined) using micro-unit intermediates. A rod attached to the master model served as a control condition to evaluate the suitability of the twenty specimens, carried out with the help of an optical stereomicroscope (Pantec, Brazil; Materials Testing Laboratory, São Leopoldo Mandic, Campinas, São Paulo).

\section{Results}

Evaluator reliability was assessed using thelntraclass Correlation Coefficient, obtaining 99.6\% (excellent). There were significant differences between groups, and the Mann-Whitney test compared groups in pairs for a more accurate result.

\section{Conclusion}

The group which presented the best behavior was open tray and condensation silicone and the worst result, that needed to be cast several times, was closed tray and condensation silicone.

Indexing terms: Adaptation. Dental implantation. Models anatomic.

\section{RESUMO}

\section{Objetivo}

Avaliar a desadaptação marginal entre intermediário micro-unit e cilindro metálicos, variando a angulação dos implantes, com dois tipos de materiais e diferentes técnicas de moldagem.

\section{Método}

Modelo com três implantes (um perpendicular ao plano horizontal e dois inclinados) usando intermediários micro-units. Uma barra mestre acoplada ao modelo serviu de situação controle para avaliar a adaptação dos vinte corpos de prova, feitas com estereomicroscópio óptico.

\section{Resultados}

A confiabilidade do avaliador foi avaliada com Índice de Correlação Intraclasse, obtendo 99,6\% (ótimo). Houve diferença estatisticamente significante entre os grupos, e com o teste Mann-Whitney comparou-se os grupos aos pares para um resultado mais preciso.

\section{Conclusão}

O grupo que apresentou melhor comportamento foi o de tray aberta e silicone por condensação. O de pior resultado, que foi preciso ser moldado diversas vezes, foi o de tray fechada e silicone por condensação.

Termos de indexação: Adaptação. Implantação dentária. Modelos anatômicos.

\footnotetext{
${ }^{1}$ Instituto Tocantinense Presidente Antônio Carlos, Curso de Odontologia. Av. Filadélfia, 568, Setor Oeste, 77.816-540, Araguaína, TO, Brasil. Correspondência para / Correspondence to: LNR LEANDRO. E-mail: < lislianerossi@hotmail.com>.

${ }^{2}$ Faculdade São Leopoldo Mandic, Curso de Odontologia, Programa de Pós-Graduação em Prótese Dentária. Campinas, SP. Brasil.

${ }^{3}$ Consultório Particular. São Paulo, SP, Brasil.
} 


\section{INTRODUCTION}

The advent of osseointegrated titanium implants has brought significant progress to Dentistry, leading to changes that have expanded therapy options in the area of rehabilitation. After the fitting of the implant, osseointegration needs to take place and be preserved for the long term, as it provides a system of anchorage for the prosthesis. This has modified and increased the number of options in the area of rehabilitation planning and treatment.

According to Jemt \& Book ${ }^{1}$ and Jemt \& Lie ${ }^{2}$ "a misfit between post and prosthesis is acceptable up to $150 \mu \mathrm{m}$ ". Kallus \& Bressing ${ }^{3}$ reported that "a misfit of $30 \mu \mathrm{m}$ would be optimal, enabling bone maturation and remodeling in response to occlusal forces, preserving the adjacent support tissue in a stable, healthy clinical condition".

The transfer molding stage is of utmost importance. Various factors, such as the transfer technique, the fixing of the transfer impressions, the pouring of the plaster and the selection of the molding material should be controlled so that replication can be as accurate as possible. The failure to observe these principles may result in prostheses with inadequate adaptation to the implants, leading to their undue movement and to extensive bone reabsorption, loose and fractured retaining screws, fractures of the prosthetic components or of the implant itself.

The Branemark protocol ${ }^{4}$ advocates the conventional technique for installing implants in which they should be located so that the functional load applied can be transmitted axially to their longitudinal axis. Inclining implants arose as an adaptation of the conventional technique and may be useful in select cases of multiple fixtures on account of anatomical or functional conditions. With inclining implants, the need for passive adaptation of the prosthetic components is imperative in order to avoid a buildup of tension which could have an adverse impact on the success of the procedure.

Bearing in mind the need to obtain passivity of the implant-supported prostheses, this paper proposes an analysis of the misfit between micro-unit posts, by varying the molding materials and techniques (open and closed tray).

\section{METHODS}

A master model was prepared $(20 \times 27 \times 11)(\mathrm{H} \times$ W x T) containing 3 implants. The central implant was fixed perpendicular to the horizontal plane of the master model while the implants at the ends were set at an angle of $15^{\circ}$ in relation to the center implant. Intermediate implants of the micro-unit type, with a height of $1 \mathrm{~mm}$ and torque of $20 \mathrm{~N} . \mathrm{cm}$, were installed on top of these implants. A rod with a circular cross-section was waxed in order to join the cylinders to the micro-unit, wrought in Cobalt-Chrome and joined to the cylinders using laser welding, with the aim of obtaining maximum passivity and the adaptation of this superstructure to the master model.

The study consisted of 4 sample groups: 1) Group $\mathrm{AF}$ - Molding through the closed tray technique using addition silicone (Elite HD, Zhermack, Italy); 2) Group AA - Molding through the open tray technique using addition silicone (Elite HD - Zhermack); 3) Group CF - Molding through the closed tray technique using condensation silicone (Zetaflow - Zhermack); 4) Group CA - Molding through the open tray technique using condensation silicone (Zetaflow - Zhermack).

In order to fabricate the individual trays, a small plaster model was made with the following dimensions: $(\mathrm{H}-$ $2 \mathrm{~cm} ; \mathrm{W}-3.5 \mathrm{~cm}$; D - $2 \mathrm{~cm}$ ). Using acrylic plates $2 \mathrm{~cm}$ thick we obtained 20 trays, 10 of which were open and 10 closed.

Replicas of the micro-units were screwed to 60 transfer impressions on the 20 moldings to obtain the models. The plaster was manipulated in a vacuum spatulator for 30 seconds in the correct proportion determined by the manufacturer $(25 \mathrm{ml}$ water/ $100 \mathrm{~g}$ powder). After 45 minutes, the models were removed from the respective molds. In this way 20 specimens were obtained, each containing 3 micro-unit analogs.

The data were obtained by measuring the vertical discrepancy of the master rod installed on the specimens with the torque recommended for this type of screw $(10 \mathrm{~N} . \mathrm{cm})$, carried out using the optical stereo microscope at a magnification of 100x (Pantec, Brazil; Materials Test Laboratory, São Leopoldo Mandic). A total of 6 readings were taken for each specimen (3 buccal and 3 lingual), making a total of 120 readings, 30 for each sample group.

The misfit variations in the specimens were compared with the misfits in the control situation (master rod on the metallic master model) and the calibration of the evaluator was tested to check the data reading baseline so the calibrator would not be a variable in the study. The results obtained were submitted for statistical analysis to check the influence of the implant angle and molding technique factors on the misfit condition.

The Mann-Whitney, Kruskall-Wallis and Intraclass Correlation Coefficient (ICC) tests were applied, carried out at a level of significance of $95 \%(p<0.05)$. 
The research study was approved by the Research Ethics Committee at the São Leopoldo Mandic Faculty under record n. 2010/173.

\section{RESULTS}

The measurement of evaluator conformity was carried out by applying the Intraclass Correlation Coefficient (ICC), which is used to measure the reliability of a variable, seeing that the Pearson correlation test is used to validate the variable. This coefficient uses a scale from zero to one hundred, i.e. ranging from poor to excellent. It was found that the value of $99.6 \%$ found in this study is considered to be statistically significant, i.e. the calibration measurement is reliable, and classified as excellent. To compare the four groups, the Kruskal-Wallis test was used, the data being described in Table 1.

Table 1. Comparison between groups.

\begin{tabular}{lcccc}
\hline & AF & AA & CF & CA \\
\hline Mean & 9.40 & 10.91 & 11.31 & 7.52 \\
Median & 7.85 & 10.41 & 9.59 & 7.28 \\
Standard deviation & 5.22 & 3.63 & 5.96 & 3.15 \\
p-value & 0.002 & & & \\
\hline
\end{tabular}

Notes: $\mathrm{AF}=$ molding via the closed tray technique using addition silicone; $\mathrm{AA}$ =molding via the open tray technique using addition silicone; $C F=$ molding via the closed tray technique using condensation silicone; $C A=$ molding via the open tray technique using condensation silicone.

An analysis of Table 1 shows that group AF was statistically different from group AA. Group AA was the same as group CF but different from group CA and group CF was also different from group CA.

\section{DISCUSSION}

The observations of Burawi et al. ${ }^{5}$, De La Cruz et al. ${ }^{6}$, Gomes et al. ${ }^{7}$ and Faria ${ }^{8}$ were in agreement with regard to the molding techniques and materials, where they represent important variables for obtaining the degree of accuracy bet ween the various components. In the study carried out by Assunção et al. ${ }^{9}$, it was found that "the under standing of the positioning of the implants is important for a passive seating of the superstructure on top of them, without interference between prosthesis and components", slightly different to Neves et al. ${ }^{10}$ where it is reported that "due to anatomical limitations, many authors have considered implant angles of up to $60^{\circ}$, which departs from the conventional position of $90^{\circ}$ in relation to the rim surface". For this reason, the master model was made with the implants at an angle of $30^{\circ}$ to each other. The reason for an inclination of $15^{\circ}$ was simply not to exacerbate the behavior of the posts inclined to their limit $\left(40^{\circ}\right)$, when using the micro-unit post. The Intraclass Correlation Coefficient (ICC) is used to measure the reliability of a variable, on a scale from 0 to 100 . It was found that the value of $99.6 \%$ found in this study is considered to be statistically significant, i.e. the calibration measurement is reliable and this correlation is excellent, thereby allowing us to conclude that neither the examiner nor the measuring technique can be regarded as a bias in the data obtained. With the closed tray technique, the variations adhere to the various types of molding materials. "The distortions inherent to this technique are normally related to the repositioning of the analog transfer impressions inside the moldings" (Spector ${ }^{11}$ ). The biggest problem observed in this study occurred with the condensation silicone and the closed tray, as in these cases the master rod did not even fit the models obtained. The open tray technique with the square transfer impressions joined with acrylic resin have been widely used since they were advocated by Branemark"1. Several authors have studied their effectiveness $8,11-12$, though the results have not been conclusive in terms of their superiority over other transfer techniques. However, Hsu et al. ${ }^{13}$ pointed out that "there was no difference in accuracy between moldings carried out using square transfer impressions, whether bonded or not", results which are seen to be in agreement with the findings of Spector et al. ${ }^{11}$, Pinto ${ }^{14}$, Goiato et al. ${ }^{15}$, Herbest et al. ${ }^{16}$ and Faria et al. ${ }^{8}$, who also found no difference between the two techniques, nor was there any difference when compared with the conical transfer impression technique. Burawi et al. ${ }^{5}$ stated that "the technique that uses transfer impressions that are not bonded is more accurate when compared to the technique that uses bonded transfer impressions, using addition silicone for the molding material". Even though this is not a study which had to endure the problems associated with day clinic settings, such as direct contact with the patient, saliva, difficulty in opening the mouth, nonetheless a certain difficulty was found in obtaining precise results with regard to a number of techniques in terms of the molding of multiple, inclined implants. Therefore it is important to stress that many other factors are involved and need to be carefully observed so that the passivity is as close as possible. 


\section{CONCLUSION}

The molding materials demonstrated distinct behaviors, to the extent that a simple analysis of the type of material did not show that there was any statistical difference which would enable us to conclude which material is most recommended for the transfer molding of inclined implants. The open tray technique tended to promote a lesser degree of misfit in the analyzed rod; the group exhibiting the best behavior, albeit insignificant in relation to the others, was the one that used the open trayand condensation silicone

\section{REFERENCES}

1. Jemt T, Book K. Prosthesis misfit and marginal bone loss in edentulous implant patients. Int J Oral Maxillofac Implants. 1996;11(5):620-5

2. Jemt T, Lie A. Accuracy of implant-supported prostheses in edentulous jaw. Clin Oral Implants Res. 1995;6(3):172-80. 10.1034/j.1600-0501.1995.060306.x.

3. Kallus $T$, Bressing C. Loose gold screws frequently occur in full fixed prostheses supported by osseointegrated implants after 5 years. Int J Oral Maxillofac Implants. 1994;9(2):169-78.

4. Branemark PI. Osseointegration and its experimental background J Prosthet Dent. 1983;50(3):399-410. doi: 10.1016/S00223913(83)80101-2.

5. Burawi G, Houston F, Byrne D, Claffey N. A comparison of the dimensional accuracy of the splinted and unsplinted impression techniques for the Bone-Lock implant system. J Prosthet Dent. 1997;77(1):68-75. doi: 10.1016/S0022-3913(97)70209-9.

6. De La Cruz JE, Funkenbusch PD, Ercoli C, Moss ME, Graser GN, Tallents RH. Verification jig for implant-supported prostheses: a comparison of standard impressions with verification jigs made of different materials. J Prosthet Dent. 2002;88(3):329-36. doi: 10.1067/mpr.2002.128070.

7. Gomes EA, Assunção WG, Costa OS, Delben JA, Barão VAR Moldagem de transferência de prótese sobre implante ao alcance do clínico-geral. Pesq Bras Odontoped Clin Integr. 2006;6(3):281-8.

8. Faria JCB, Silva-Concilio LR, Neves ACC, Miranda ME, Teixeira ML. Evaluation of the accuracy of different transfer impression techniques for multiple implants. Braz Oral Res. 2011;25(2):1637. doi: 10.1590/S1806-83242011000200011.
(CA) and the group that demonstrated the poorest results was the one that used the closed tray and condensation silicone, since the moldings in this group had to be repeated several times as the master rod did not permita fitting to the models obtained.

\section{Collaborators}

LNR LEANDRO, RB BRITO, ML TEIXEIRA, LM TURANO, LM CUNHA took part in all stages of the process of preparing this article.

9. Assunção WG, Gennari Filho H, Zaniquelli O. Evaluation of transfer impressions for osseointegrated implants at various angulations. Implant Dent. 2004;13(4):358-66.

10. Neves FD, Oliveira MRS, Fernandes Neto AJ, Lima JHF. Seleção de intermediários para implantes Bränemark compatíveis. Parte I: casos de implantes múltiplos. BCI. 2000;7(25):6-19.

11. Spector MR, Donovan TE, Nicholls Jl. An evaluation of impression techniques for osseointegrated implants. J Prosthet Dent. 1990;63(4):444-7

12. Humphries RM, Yaman P, Bloem TJ. The accuary of implant master casts constructed from transfer impressions. Int J Oral Maxillofac Implants. 1990;5(4):331-6

13. Hsu CC, Millstein PL, Stein RS. A comparative analysis of the accuracy of implant transfer techniques. J Prosthet Dent. 1993;69(6):588-93. doi: 10.1016/0022-3913(93)90287-X.

14. Pinto JHN, Valle AL, Scolaro JM, Bonfante G, Pegoraro LF Estudo comparativo entre técnicas de moldagens para implantes odontológicos. Rev Fac Odontol Bauru. 2001;9(3-4):167-72.

15. Goiato MC, Domitti SS, Consani S. Influência dos materiais de moldagem e técnicas de transferência em implante, na precisão dimensional dos modelos de gesso. JBC J Bras Odontol Clín. 1998;2(8):45-50.

16. Herbst D, Nel JC, Driessen CH, Becker PJ. Evaluation of impression accuracy for osseointegrated implant supported superstructures. J Prosthet Dent. 2000;83(5):555-61.

Received on: 9/8/2012 Final version resubmitted on: 2/4/2013 Approved on: 4/7/2013 